\title{
ICT Implementation for Materials Management in Construction Projects: Case Studies
}

\author{
Narimah Kasim ${ }^{1}$
}

\begin{abstract}
Construction materials usually constitute a major portion of the total cost in a building construction project. Materials management is made problematic by materials shortages, delays in supply, price fluctuations, damage and wastage, and lack of storage space. Despite the potential benefit of ICT, convincing construction organisations to embrace its use and implementation has proved a difficult task. This study seeks to identify the implementation of ICT for materials management processes in construction projects. The findings from the case studies reveal that the implementation of ICT in the materials management processes for construction projects in Malaysia is at early stage. Microsoft Excel Spreadsheet and handheld devices are found to be the common ICT tools adopted in the materials management processes. The main barrier is found to be the cost involvement at the initial stage or overall implementation of ICT in the materials management processes. Finally, this paper concludes the finding from interviews towards the ICT implementation of materials management in the construction projects.
\end{abstract}

Keywords: Construction Projects, Construction Materials, Materials Managements, ICT

\section{INTRODUCTION}

Materials management functions include planning and taking off materials, vendor evaluation and selection, purchasing, expenditure, shipping, material receiving, warehousing and inventory, and material distribution [1]. Almost $60 \%$ of the total working capital of any industrial organisation consists of materials costs [2]. Materials management can only produce what it should with the right quantities of the right material at the right time [3]. Thus, any improper handling and managing of materials will cause a huge effect on the total project cost, time and quality.

Information and Communication Technology (ICT) is a wide-ranging term that includes all technologies for the manipulation and communication of information. For instance, the internet is widely used for electronic mail (email) and electronic commerce (e-commerce) including electronic invoicing, payments and receipt of materials process [4]. Apart from that, more sophisticated solutions of ICT based technologies are emerging such as wireless communication, bar-coding and Radio Frequency Identification (RFID) for tagging technologies. Thus, an appropriate implementation of ICT could facilitate more effective and productive materials management processes.

Generally, the construction industry in Malaysia has lagged behind other industries in embracing ICT. It was found that although the professionals are quick to assimilate computerisation into their construction processes, the contractors and builders are still far from the adoption of
ICT [5]. In the international construction industry, Turkey and other countries faced similar challenges in the area of communication and loss of information [6]. Accordingly, the implementation and practice of ICT in materials management will strongly ease unnecessary lost and increase productivity in any projects. Thus, there is clearly a need to explore on the existing ICT implementation of the contractors while studying the availability for ICT to be implemented. Other than that, current constraints that are hindering the acceptance of ICT in materials management processes will also be identified.

The purpose of this research is to study the implementation of ICT for materials management in construction projects. Therefore, this study investigating the ICT implementation of materials management processes in construction projects. Apart from that, it is essential to examine the acceptance of contractors towards the transformation of ICT implementation in materials management processes. Thus, there is a need to explore on the area of materials management, the issues relating to materials management problems and the implementation of ICT in materials management.

\section{MATERIALS MANAGEMENT}

Materials management is defined as a coordinating function responsible for planning and controlling materials flow [3]. In a detailed view, materials management is a planned procedure that comprises the purchasing, delivery,

\footnotetext{
${ }^{1}$ Senior Lecturer, Faculty of Technology Management, Business \& Entrepreneurship, Universiti Tun Hussein Onn Malaysia, 86400 Parit Raja, Batu Pahat, Johor, narimah@uthm.edu.my (*Corresponding Author)
} 
handling and minimisation of waste with the aim of ensuring that requirements are met [7].

Materials management is an essential function that improves productivity in construction projects. Hence, the efficient use and management of material have an important influence on a company's profit and can avoid delay in construction [8].

In order to better understand materials management the following processes are discussed: planning, procurement, logistics, handling, stock and waste control.

- Planning: Materials planning includes quantifying, ordering and scheduling. It is stressed that planning is especially significant in terms of increasing productivity, profit, and facilitating the timely completion of construction projects [9]. Hence, productivity will suffer if the material planning process is not executed properly.

- Procurement: Procurement is described as the purchase of materials and services from outside organisations to support the firm's operations from production to marketing, sales and logistics [10]. As such, a detailed material schedule and co-ordination of the procurement and order of material are important in assuring material availability [11].

- Logistics: Generally, logistics is a concept that emphasises movement and it may include planning, implementing, and controlling the flow and storage of all goods from raw materials to the finished product to meet customer requirements [12]. There is evidence that the routing of materials is one of the main points which affect cost and time during construction projects [13].

- Handling: Handling of materials is the flow component that provides for their movement and placement. Due to the frequency of handling materials there are quality considerations when designing a materials handling system. Materials handling equipment selection is an important function as it can enhance the production process, provide effective utilization of manpower, increase production and improve system flexibility [14].

- Stock and Waste Control: Stock control is classified as a technique devised to cover and ensure all items are available when required. Stock control can include raw materials, processed materials, assembly components, consumable stores, general stores, maintenance materials and spares, work in progress and finished products [15]. It is of great importance that the bulk of construction materials delivery requires proper management of stock control.

Meanwhile, it is said that construction activities can generate an enormous amount of waste [16] and materials waste has been recognised as a major problem in the construction industry [17]. However, tighter materials planning can reduce waste and can directly contribute to profit-improvement and productivity [18].
Each processes stated above plays an important role for an effective materials management. However, there are materials management issues that have not yet been tackled effectively. The following section will highlight on the current materials management problems faced in the construction industry.

\section{MATERIALs MANAGEMENT PROBLEMS}

It is gathered that current manual materials management practices and control procedures are unsatisfactory as they are labour intensive, inaccurate and error prone. The implication leads to waste and surplus of materials, delays, decrease in productivity and lack of upto-date and real-time information [19].

Interestingly, many problems related to management surface amongst local contractors even in developing countries. The problems normally vary in nature and intensity but are usually related to the inefficient management of construction resources including materials, labour, plant and subcontractors [14].

Few main materials management problems were being identified in the construction industry in the UK and are summarised as below [20]:

- Lack of site storage space

- Problems with tower crane distribution

- Problems on logistic of materials

- Small loading area

- Problem with one site access point

- Difficulty in delivery of materials on site during aircraft operation

- Operation limitation due to security considerations

- Inadequate loading area at consolidation centre

- Problems with congestion time at loading area

A survey in the construction productivity in Iran reveals the major causes of the lack in productivity boils down to the improper deposited material, improper material handling, improper material application and improper material deliveries [21].

Due to the fact that the problems in materials management will be never ending, it is plausible that ICT implementation may be the answer to overcome the challenge of materials management in the construction industry. The dilemmas faced in materials management can be overcome by adapting ICT-enabled solution that can help support the effective management of materials activities.

\section{ICT IMPLEMENTATION IN MATERIALS MANAGEMENT}

Information Technology (IT) can be defined as the use of electronic machines and programmes for the processing, storage, transfer and presentation of information. Communication technology is today an important part of IT [3]. Together; they make up for the term ICT.

Mobile devices range from Notebooks, personal digital assistants (PDA), portable data terminals (PDT), tablet 
personal computers to smart phones. Today, these devices have increased in style, functionality, capacity, application areas, features, usability, etc. Apart from that, RFID is also used in materials identification on construction projects in order to reduce the level of confusion regarding materials delivery from suppliers, and the relevant location at the jobsite [22].

Accordingly, construction organisations are recognising the benefits of automating the materials handling process, including increased productivity, better space utilisation, higher customer service levels, reduced operating expenses and improved flow of materials [23]. For instance, integrating promising information technologies such as RFID technology, mobile devices-PDA and web portals can help improve the effectiveness and convenience of information and material flow in construction supply chain control systems. Previous researches have proven that adoption of ICT is essential in order to overcome the materials management problems inherent within the construction industry. Moreover, it is found that the effective implementation of ICT has the huge potential to bring about significant improvements.

However, in regard to the adoption of ICT for building project management in the Indian construction industry, mobile internet had been used only by $15 \%$ of the surveyed organisations for project management. It was even more apparent that RFID and bar-coding had not been used by any of the surveyed organisations for materials management [24]. Apparently, this low acceptance to ICT adoption contradicts with the findings above. Despite the advancement of technologies designed to facilitate materials management processes, it appears that a resistance towards effective implementation of ICT still exist in the current construction world. Consequently, it has deterred the construction industry from moving rapidly forward [25].

The challenges existing in the current materials management chain has clearly raised the importance to explore on the awareness of the players in the construction industry towards the adoption of ICT in the management of materials. Thus, a constructive research methodology was derived to study on the related issues stated in this paper.

\section{Case Studies Project}

Case studies involving five construction projects were undertaken, to investigate the implementation of ICT in materials management processes in construction projects. The case studies were also used to examine the main barrier towards transformation of ICT implementation in materials management processes.

This study is based on five construction organisations (cases). The most appropriate construction organisations to involve in the case studies were first identified. The case studies were carefully and deliberately selected according to main criteria; Class A contractors (the highest contractor classification in Malaysia with financial limit RM 4 million and above), attempted to implement ICT, and the willingness of individuals within the organisations to participate. The interview was done in the state of Johor which is the southern area of the Peninsular Malaysia. Background information on the five construction organisations involved in the case studies are presented in Table 1.

TABLE 1

LIST OF CASE STUDIES

\begin{tabular}{|c|c|c|}
\hline Case & Organisation & Project \\
\hline 1 & Triowell Construction & Sewerage Line \\
\hline 2 & KTC (Kien Tat Construction) & Road and Drainage \\
\hline 3 & PTJ (Pembinaan Titis Jaya) & Building \\
\hline 4 & YICAI Construction & Building \\
\hline 5 & Wann Bina Construction & Drainage \\
\hline
\end{tabular}

The construction organisations were visited, and semistructured interviews took place with those responsible in managing construction projects such as project manager, site manager and site coordinator. Each interview lasted between 45 minutes and an hour. All the data from interviews was recorded and transcribed verbatim.

For the purpose of this research, the 'unit of analysis' is geared towards achieveing the study objective, which is to gain the information of current ICT implementation and barriers towards ICT implementation in materials management processes. The 'unit of analysis' for this study is based on the five construction projects and six 'embedded units of analysis' as follows:

- Embedded Unit of Analysis 1: ICT implementation;

- Embedded Unit of Analysis 2: ICT implementation in materials management processes;

- Embedded Unit of Analysis 3: Benefit of ICT implementation;

- Embedded Unit of Analysis 4: Effectiveness of ICT implementation;

- Embedded Unit of Analysis 5: Main barriers towards ICT implementation; and

- Embedded Unit of Analysis 6: Benefits of emerging technologies (i.e. bar-coding and RFID) implementation.

Cross-case analysis was used to make a comparison of the embedded unit of analysis across the various case studies [26]. This involved the examination of the six 'embedded unit of analysis' between each case study to provide the key findings from an argumentative interpretation.

\section{DISCUSSION AND ANALYSIS}

Table 2 below are summarised the types of ICT tools used, the materials management processes that ICT is more commonly implemented, benefits and effectiveness of ICT implementation, main barriers towards ICT implementation and the benefits of bar-coding and RFID in materials management processes.

In the consideration of the main ICT tools which are 
implemented in materials management processes, all 5 cases emphasised on the basic implementation of Microsoft Word and Excel in the materials management processes. Every case, except for Cases 3 and 5, considers Microsoft Project and Access as their main ICT tool. ICT tools such as the usage of laptop, personal computer, and mobile phone are common for all cases. Only Cases 2 and 3 utilise the handheld device which is the walkie-talkie in materials management at the construction site. The use of PDA is considered a main ICT tool for materials management by Cases 2, and 4 and only Case 4 implements wireless service (Bluetooth and $\mathrm{WiFi}$ ) in the processes of materials management. Case 4 explains that the Bluetooth and $\mathrm{WiFi}$ services are normally used in the transition of information e.g. pictures of construction for the progress report purpose.

Among the main processes of materials management, the planning and procurement are processes considered by all the cases, except for Case 4 as needing the highest investment of ICT implementation. Cases 3 and 4 regarded logistics process as needing the highest investment in ICT implementation.

There was a significant wide range of answers given by all cases on the benefits of the existing ICT practices in the materials management processes. Case 1 highlighted on the overall effectiveness and wastage control of materials management processes which he considered are due to the systematic processes when ICT is being practiced. According to Case 2, time saving and convenience of network system as the main benefits when ICT is practiced in the materials management processes. Case 3 believes in the improved material control and enhanced material procurement (especially in pricing of products) as the advantages in the existing ICT implementation in materials management. In addition, Case 4 stressed that the benefits of the existing ICT practices comprised of a better budget control, improved record tracking, lessened paperwork and effective material delivery. Case 5 agreed with Case 2 regarding time saving as a benefit of ICT implementation. Besides that, Case 5 regards effectiveness of cost control as the result of the existing ICT practices in materials management.

Next, the interviewees are asked on the extent of the effectiveness of ICT implementation in materials management, whereby all interviewees believe that it can be highly effective, in certain degree and in certain aspects. Case 1 believed in an increment of 10-20\% effectiveness of materials management at site. In addition, effective delivery and documentation will enhance the effectiveness of the materials control and planning processes respectively when
ICT is incorporated in materials management processes. According to Case 2, the overall processes in materials management will be very fast and information tracking can be done easily even if it is dated many years back with implementation of ICT. However, Case 3 made it clear that the implementation of ICT can only bring effectiveness in the materials management if there is a developed system to be managed. If there is not, all efforts for ICT implementation will be redundant. Case 4 mentioned with a strong emphasis on the effectiveness in the interlinking of information, information obtained from PDA and effective communication when ICT is incorporated in materials management. Case 3 pointed out that the effectiveness of ICT implementation also depended on certain aspects, Case 5 highlighted that the implementation of ICT can be very effective but with a condition that application of ICT has the full acceptance of the suppliers and personnel as well.

In the question to study the acceptance of the ICT transformation, the 5 cases are asked to give details to the main barriers they face. All cases directed the main barriers to the high cost involvement and the inadequacy of expertise of their staffs. Case 1 also mentioned the need to train workers to adapt ICT whereas Cases 2 and 3 discussed about the uncertainty of the return of investment. Besides that, Cases 3 and 5 included the supplier to be one of the main barriers as not being able to cope with and provide their service to the ICT transformation in materials management processes.

Bar-coding and RFID are under the category of sophisticated ICT tools. The interviewees are asked on the benefits they believe can be attained in the implementation of bar-coding and RFID in materials management processes. Case 1 suggested that bar-coding and RFID enable more convenient tracking and identification of material, thus making the follow up on material quantity an easy task. Case 2 believed that there will be improved material flow, lower operation expenses, lesser defect, effective info tracking, higher productivity and better space utilisation. Case 3 suggested that the implementation of bar-coding will improve the controlling and handling of material quantity as it is based on serial numbers. However, Case 3 has no knowledge of the benefits of RFID. Case 4 gave the same benefits with Case 2, and pointed out that handling of materials can just be executed from a spot. As for Case 5, he stated that bar-coding and RFID are able to improve material flow for expensive materials from factory, but bring lesser benefits in infrastructure works. 
TABLE 2

ELEMENT OF ANALYSIS

\begin{tabular}{|c|c|c|c|c|c|}
\hline Elements of Analysis & Case 1 & Case 2 & Case 3 & Case 4 & Case 5 \\
\hline 1) ICT implementation & $\begin{array}{l}\text { - } \text { Microsoft (Excel, } \\
\text { Project, Access) } \\
\text { - Laptop } \\
\text { - Mobile phone } \\
\text { - Fax }\end{array}$ & $\begin{array}{l}\text { - } \text { Microsoft (Word, } \\
\text { Excel, Project, Access) } \\
\text { - Personal computer, } \\
\text { Laptop } \\
\text { - PDA } \\
\text { - Mobile phone } \\
\text { - Walkie-talkie }\end{array}$ & $\begin{array}{ll}\text { - } & \text { Microsoft (Word, } \\
& \text { Excel) } \\
\text { - } & \text { Computer } \\
\text { - } & \text { Mobile phone } \\
\text { - } & \text { Walkie-talkie }\end{array}$ & $\begin{array}{l}\text { - } \text { Microsoft (Excel, } \\
\text { Project, Access) } \\
\text { - Personal Computer, } \\
\text { Laptop } \\
\text { - Mobile phone } \\
\text { - PDA (provide } \\
\text { directions) } \\
\text { - WiFi and Bluetooth } \\
\end{array}$ & $\begin{array}{l}\text { - Microsoft } \\
\text { (Excel,Word) } \\
\text { - Laptop } \\
\text { - Mobile phone }\end{array}$ \\
\hline $\begin{array}{l}\text { 2) ICT implementation in } \\
\text { materials management } \\
\text { processes }\end{array}$ & $\begin{array}{ll}\text { - } & \text { Planning } \\
\text { - } & \text { Procurement: } \\
& \text { Purchase }\end{array}$ & $\begin{array}{ll}\text { - } & \text { Planning } \\
\text { - } & \text { Procurement }\end{array}$ & $\begin{array}{l}\text { - Planning: } \\
\text { Budgeting } \\
\text { - Logistics }\end{array}$ & $\begin{array}{l}\text { - Procurement } \\
\text { - Logistics }\end{array}$ & $\begin{array}{l}\text { - Planning } \\
\text { - Procurement }\end{array}$ \\
\hline $\begin{array}{l}\text { 3) Benefits of ICT } \\
\text { implementation }\end{array}$ & $\begin{array}{l}\text { - Effective } \\
\text { - Systematic } \\
\text { - Wastage control }\end{array}$ & $\begin{array}{l}\text { - Time saving } \\
\text { - Convenient network } \\
\text { system }\end{array}$ & $\begin{array}{l}\text { - Improve material } \\
\text { control } \\
\text { - Enhance material } \\
\text { procurement } \\
\text { (pricing) }\end{array}$ & $\begin{array}{l}\text { - } \text { Budget control } \\
\text { - Record tracking - } \\
\text { pricing, quantifying } \\
\text { - Less paperwork } \\
\text { - Effective material } \\
\text { delivery }\end{array}$ & $\begin{array}{l}\text { - Cost control } \\
\text { - Time saving }\end{array}$ \\
\hline $\begin{array}{l}\text { 4) Effectiveness of ICT } \\
\text { implementation }\end{array}$ & $\begin{array}{l}\text { 10-20\% more } \\
\text { effective at site } \\
\text { - Material control } \\
\text { delivery } \\
\text { - Planning: } \\
\text { documentation }\end{array}$ & $\begin{array}{l}\text { - } \text { Very fast } \\
\text { - Previous information } \\
\text { tracking }\end{array}$ & $\begin{array}{l}\text { - Very effective (if } \\
\text { there's a system } \\
\text { to manage) }\end{array}$ & $\begin{array}{l}\text { - Information linking } \\
\text { - Information can be } \\
\text { obtained from PDA } \\
\text { - Effective } \\
\text { communication }\end{array}$ & $\begin{array}{l}\text { - Very effective } \\
\text { - Depends on the } \\
\text { acceptance of } \\
\text { supplier and } \\
\text { personnel }\end{array}$ \\
\hline $\begin{array}{l}\text { 5) Main barriers towards } \\
\text { ICT implementation }\end{array}$ & $\begin{array}{l}\text { - } \text { Cost } \\
\text { - The need to train } \\
\text { workers }\end{array}$ & $\begin{array}{l}\text { - Maintenance cost } \\
\text { - Staff specialist } \\
\text { - Uncertain Return of } \\
\text { Investment }\end{array}$ & $\begin{array}{l}\text { - } \text { High cost } \\
\text { - Providence of } \\
\text { manpower - staff } \\
\text { and skill } \\
\text { - Uneducated site } \\
\text { supervisor } \\
\text { - Return of } \\
\text { investment } \\
\text { uncertain } \\
\text { - Supplier } \\
\text { problems } \\
\text { (transport and } \\
\text { machinery) }\end{array}$ & $\begin{array}{l}\text { - Very high cost of } \\
\text { implementation for } \\
\text { overall } \\
\text { - Staff education level } \\
\text { (even if } 10 \text { years to } \\
\text { come, labour may } \\
\text { still be unable to } \\
\text { adapt) }\end{array}$ & $\begin{array}{l}- \text { Cost } \\
\text { - Staff } \\
\text { - Supplier }\end{array}$ \\
\hline $\begin{array}{l}\text { 6) Benefits of emerging } \\
\text { technologies (i.e. bar- } \\
\text { coding and RFID) } \\
\text { implementation }\end{array}$ & $\begin{array}{l}\text { - Convenient tracking } \\
\text { and identification of } \\
\text { materials } \\
\text { - Easier to follow up } \\
\text { on material quantity }\end{array}$ & $\begin{array}{l}\text { - Improve material flow } \\
\text { - Lower operation } \\
\text { expenses } \\
\text { - Lesser defect } \\
\text { - Effective information } \\
\text { tracking } \\
\text { - Higher productivity } \\
\text { - Better space utilisation }\end{array}$ & $\begin{array}{l}\text { - Bar-code: } \\
\text { controlling, } \\
\text { handling material } \\
\text { quantity based on } \\
\text { serial numbers } \\
\text { - RFID (no } \\
\text { knowledge) }\end{array}$ & $\begin{array}{l}\text { - Improve material } \\
\text { flow } \\
\text { - Lower operation cost } \\
\text { - Reduce defects } \\
\text { - Space saving, more } \\
\text { - } \text { effective storage } \\
\text { - One person operation }\end{array}$ & $\begin{array}{l}\text { - Improve material } \\
\text { flow for } \\
\text { expensive } \\
\text { materials from } \\
\text { factory } \\
\text { - Lesser benefits in } \\
\text { infrastructure work }\end{array}$ \\
\hline
\end{tabular}

\section{IMPLEMENTATION OF ICT IN MATERIALS MANAGEMENT PROCESSES}

Generally, the main tools that are implemented in the materials management processes are the Microsoft Offices and handheld devices. In Malaysia, the applications of Microsoft Offices, walkie-talkie and mobile phone are widespread in the construction industry. However, the usage of PDA is only common for mega projects whilst bar-coding and RFID is totally nonexistent. One possible explanation behind the limited usage of ICT tools might be the lack of awareness to the benefits in ICT implementation among the contractors. Moreover, contractors handling small to average projects might doubt for a good return of investment, thus conferring to the lowest usage of ICT as possible.
Accordingly, materials planning and procurement are the main ICT-embracing processes. It is apparent that these processes are seen as the most critical start up point of a project, hence the greater extent of ICT adoption. Another possible explanation might be other processes such as materials logistics and handlings require a greater investment in ICT tools such as bar-coding tools for tracking materials.

The findings have demonstrated that Microsoft Excel and Microsoft Project are the most common ICT tools in the current industry's practice. They are perceived as the less costly ICT tools that contractors could afford investing in. However, bar-coding and RFID are tools under the category of sophisticated ICT tools. These tools 
are hardly adopted by any of the respondents in their materials management. Nevertheless, among the benefits cited by the respondents are the improved material flow and the convenience of tracking and identification of materials. With the availability of bar-coding and RFID, the monitoring of materials management will be effective, thus improving the materials flow and tracking.

\section{CONCLUSIONS}

Based on the purpose of this study in order to investigate the implementation of ICT in materials management, the main tools that are widely adopted by the respondents are the Microsoft Offices and handheld devices. Subsequently, planning and procurement are the materials management processes considered needing the highest investment of ICT implementation. Evidently, bar-coding and RFID are tools that are hardly adopted in the materials management of each respondent's company.

Nevertheless, ICT transformation was deemed vital especially in the area of cost effectiveness and in materials handling. On the other hand, the main reasons of resistance towards the increased level of implementing ICT in materials management are due to the high cost involvement whether in the maintenance or overall implementation. In addition, the exceptional high cost of specialist software is also a barrier to the upgrading of ICT implementation.

\section{ACKNOWLEDGEMENT}

The authors would like to thank the Ministry of Higher Education, Malaysia for supporting this research under the Fundamental Research Grant Scheme (FRGS).

\section{REFERENCES}

[1] L.C. Bell, G. Stukhart, "Attributes of materials management systems", Journal of Construction Engineering Construction Engineering and Management, vol. 112, no. 1, pp. 14-22, 1986.

[2] P.K. Dey, "Re-engineering materials management: A case study on an Indian refinery", Business Process Management Journal, vol. 7 , no. 5, pp. 394-408, 2001.

[3] J.R. Arnold, S.N. Chapman, "Introduction to Materials Management", $5^{\text {th }}$ ed., New Jersey: Prentice-Hall, 2004.

[4] F. Harris, R. MacCaffer, "Modern Construction Management", London: Blackwell Science, 2001.

[5] New Strait Times, "Leverage on ICT in Construction Industry", 13 May, Malaysia, 2007.

[6] M. Sarshar and U. Isikdag, "A survey of ICT use in the Turkish construction industry", Journal of Engineering, Construction and Architectural Management, 11(4), pp. 238-247, 2004

[7] J. Illingworth, K. Thain, "Material Management is it Worth It?", Technical Information Service, The Chartered Institute of Building ASCOT, 1998.

[8] H. Abdul-Rahman, M.N. Alidrisyi, "A Perspective of Material Management Practices in a Fast Developing Economy: the case of Malaysia", Construction Management and Economics, vol. 12, no.5, pp. 413-422, 1994.

[9] E.T.T. Wong, G. Norman, "Economic evaluation of materials planning systems for construction", Construction Management and Economics, vol. 15, no. 1, pp. 39-47, 1997.

[10] D.M. Lambert, J.R. Stock, L.M. Ellram, "Fundamentals of Logistics Management”, United States: McGraw Hill, 1998.
[11] O.S. Ademeso, A.O. Windapo, "Relationship between Material Management Approach and Scheduled Project Completion Time", Construction and Building Research of the Royal Institution of Chartered Surveyors Conference, COBRA, Dublin Institute of Technology, 2008.

[12] L.S. Pheng, C.J. Chuan, "Just-in-time management in precast concrete construction: a survey of the readiness of main contractors in Singapore", Integrated Manufacturing Systems, vol.12, no. 6, pp.416-429, 2001.

[13] K. Varghese, J.T. O’Connor, "Routing large vehicles on industrial construction sites", Journal of Construction Engineering and Management, vol. 121, no. 1, pp. 1-12, 1995.

[14] F.T.S. Chan, "Design of Materials handling Equipment Selection System: An Integration of Expert System with Analytic Hierarchy Process Approach", Integrated Manufacturing Systems, vol. 13, no. 1, pp. 58-68, 2002.

[15] V. Prabu, M. Baker, "Materials Management", UK: McGraw-Hill, 1986.

[16] M.M.M. Teo, M. Loosemore, "A theory of waste behaviour in the construction industry", Journal of Construction Management and Economics, vol. 19, no. 7, pp. 741-751, 2001.

[17] C.T. Formoso, L. Soibelman, C.D. Cesare, E.L. Isatto, "Materials waste in building industry: Main causes and prevention", Journal of Construction Engineering and Management, vol. 128, no. 4, pp. 316-325, 2002.

[18] A.K. Datta, "Materials Management: Procedures, text and cases", Rev. ed., New Delhi: Prentice-Hall, 1992

[19] R. Navon, O. Berkovich, "An automated model for materials management and control", Journal of Construction Management and Economics, vol. 24, no. 6, pp. 635-646, 2005.

[20] N.B. Kasim, C.J. Anumba, A.R.J. Dainty, "Improving materials management practices on fast-track construction projects", 21st Annual ARCOM Conference, 7-9 September 2005, SOAS, University of London, vol. 2, pp. 793-802, 2005.

[21] M. Zakeri, P. Olomolaiye, G.D. Holt, F.C. Harris, "A Survey of constraints on Iranian construction operatives' productivity" Journal of Construction Management and Economics, vol. 14, no. 5, pp. 417-426, 1996.

[22] E.J. Jaselskis, M.R. Anderson, C.T. Jahren, Y. Rorriguez, S. Njos, "Radio-Frequency Identification Applications in Construction Industry", Journal of Construction Engineering and Management, vol. 121, no. 2, pp. 189-196, 1995.

[23] T. Andel, "Automatic Data Identification: For your own good", Transportation and Distribution, vol. 34, no. 10, pp. 76-88, 1993.

[24] V. Ahuja, J. Yang, R. Shankar, "Study of ICT adoption for building project management in Indian Construction Industry", Automation in Construction, vol. 18, no. 4, pp. 415-423, 2009.

[25] P. Ang, N.B. Kasim, "Implementation of ICT in Materials Management in Construction Projects", Degree Thesis, University Tun Hussein Onn Malaysia, January 2009

[26] R.K. Yin, "Case Study Research Design and Methods", $3^{\text {rd }}$ ed., Sage Publication, United Kingdom, 2003. 